\section{Review Article}

Check for updates

\title{
Regulation of Osteoclast Differentiation by Cytokine Networks
}

\author{
Dulshara Sachini Amarasekara, Hyeongseok Yun, Sumi Kim, Nari Lee, Hyunjong \\ Kim, Jaerang Rho*
}

OPEN ACCESS

Received: Dec 4, 2017

Revised: Feb 2, 2018

Accepted: Feb 3, 2018

*Correspondence to Jaerang Rho

Department of Microbiology and Molecular Biology, Chungnam National University, 99

Daehak-ro, Yuseong-gu, Daejeon 34134, Korea.

E-mail: jrrho@cnu.ac.kr

Copyright ( 2018. The Korean Association of Immunologists

This is an Open Access article distributed under the terms of the Creative Commons Attribution Non-Commercial License (https:// creativecommons.org/licenses/by-nc/4.0/) which permits unrestricted non-commercial use, distribution, and reproduction in any medium, provided the original work is properly cited.

Conflict of Interest

The authors declare no potential conflicts of interest.

Abbreviations

ACPA, anti-citrullinated protein antibody; AP-1, activator protein 1; $\mathrm{CCL}, \mathrm{C}-\mathrm{C}$ motif chemokine ligand; C-Fms, colony-stimulating factor-1 receptor; $\mathrm{CXCL}, \mathrm{C}-\mathrm{X}-\mathrm{C}$ motif chemokine ligand; GM-CSF, granulocyte-macrophage colony stimulating factor; IL-6R, IL-6 receptor; MAPK, mitogen-activated protein kinase; M-CSF, macrophage colony-stimulating factor; MIF, migration inhibitory factor; NFATc1, nuclear factor of activated T cells 1; NO, nitric oxide; $\mathrm{OB}$, osteoblast; $\mathrm{OC}$, osteoclast; OPG, osteoprotegerin; OSCAR, osteoclastassociated receptor; PI3K, phosphoinositide 3-kinase; PLCY2, phospholipase C Y2; RA, rheumatoid arthritis; RANK, receptor activator
Department of Microbiology and Molecular Biology, Chungnam National University, Daejeon 34134, Korea

\section{ABSTRACT}

Cytokines play a pivotal role in maintaining bone homeostasis. Osteoclasts (OCs), the sole bone resorbing cells, are regulated by numerous cytokines. Macrophage colony-stimulating factor and receptor activator of NF- $\mathrm{kB}$ ligand play a central role in OC differentiation, which is also termed osteoclastogenesis. Osteoclastogenic cytokines, including tumor necrosis factor- $\alpha$, IL-1, IL-6, IL-7, IL-8, IL-11, IL-15, IL-17, IL-23, and IL-34, promote OC differentiation, whereas anti-osteoclastogenic cytokines, including interferon (IFN)- $\alpha$, IFN- $\beta$, IFN- $\gamma$, IL-3, IL-4, IL-10, IL-12, IL-27, and IL-33, downregulate OC differentiation. Therefore, dynamic regulation of osteoclastogenic and anti-osteoclastogenic cytokines is important in maintaining the balance between bone-resorbing OCs and bone-forming osteoblasts (OBs), which eventually affects bone integrity. This review outlines the osteoclastogenic and antiosteoclastogenic properties of cytokines with regard to osteoimmunology, and summarizes our current understanding of the roles these cytokines play in osteoclastogenesis.

Keywords: Cytokines; Osteoclast differentiation factor; Osteoclastogenesis; Osteoimmunology

\section{INTRODUCTION}

Bone tissue integrity is preserved by maintaining a fine balance between the activity of bone-forming osteoblasts (OBs) and bone-resorbing osteoclasts (OCs), which ensures no net change in bone mass (Fig. 1). Osteoimmunology is an interdisciplinary approach combining the study of bones and the immune system, which has disclosed numerous previously unknown facts on physiological and pathophysiological bone regulation (1-3). In particular, our understanding of the involvement of the immune system in various bone diseases, such as rheumatoid arthritis (RA), periodontal diseases, and osteoporosis, has recently been greatly expanded (3).

The discovery of the receptor activator of NF-KB (RANK)/RANK ligand (RANKL)/ osteoprotegerin (OPG) axis in the mid-1990s has resulted in immense advances in the field of osteoimmunology (3). RANKL (which is also known as tumor necrosis factor [TNF]-related activation-induced cytokine, OPG ligand, OC differentiation factor, and TNF ligand superfamily member 11) is expressed by OBs, stromal cells, and activated T cells (4). The RANKL-RANK signaling axis mainly regulates OC differentiation and bone resorption $(1,3)$. OPG, also known 


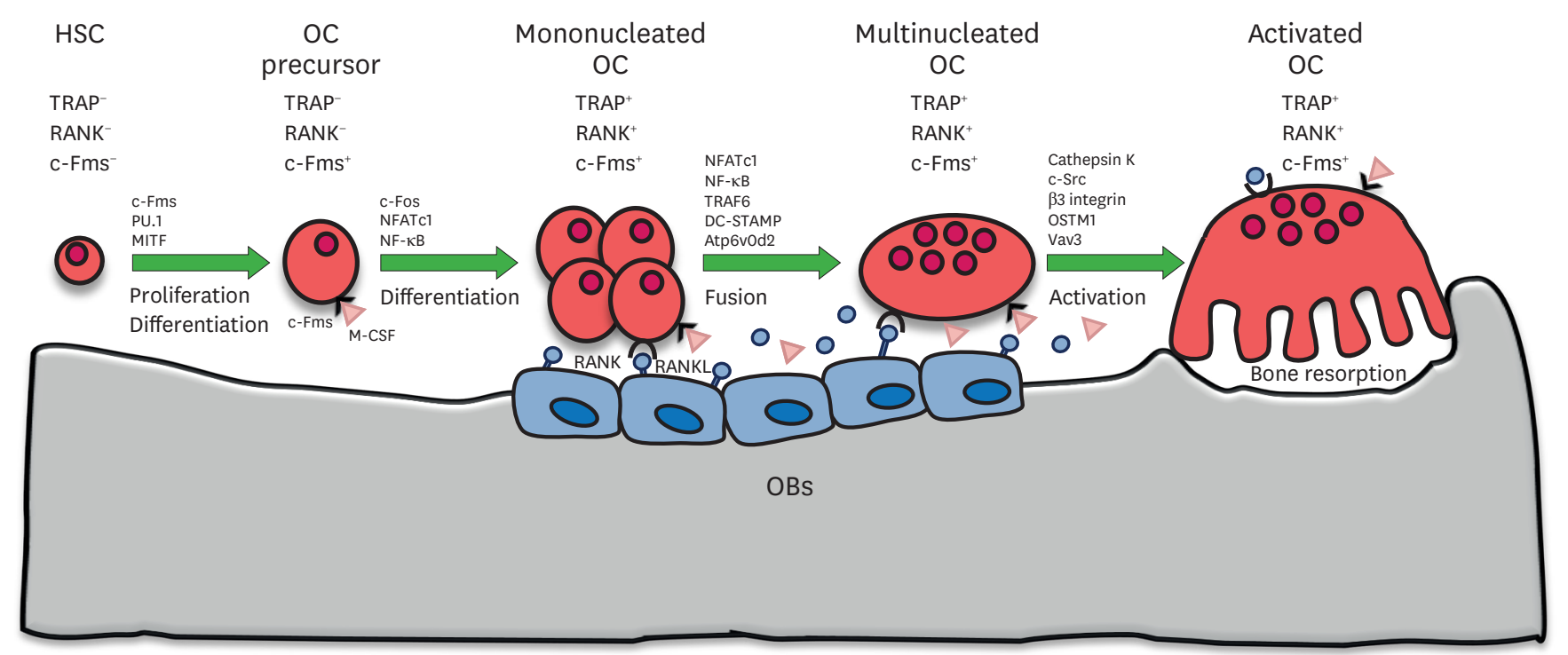

Figure 1. Schematic representation of OC differentiation and activation. HSCs undergo differentiation into OC precursors depending on the presence of PU.1 and the MITF transcription factors activated by M-CSF signaling. The differentiation of OC precursors into mononuclear and multinucleated OCs is further modulated by RANKL and M-CSF signaling. Bone-resorbing multinucleated OCs derived from the fusion of mononuclear OCs express OC differentiation markers such as DCSTAMP, Atp6v0d2, $\beta 3$ integrin, cathepsin K, and OSTM1.

Atp6v0d2, v-ATPase subunit d2; DC-STAMP, dendritic cell-specific transmembrane protein; HSCs, hematopoietic stem cell; MITF, microphthalmia transcription factor; OSTM1, osteopetrosis-associated transmembrane protein 1.

of NF-KB; RANKL, receptor activator of NF-KB ligand; STAT3, signal transducer and activator of transcription 3; Th17, T helper 17; TLR, toll-like receptor; TNF, tumor necrosis factor; TNFR, tumor necrosis factor receptor; TRAF, tumor necrosis receptor-associated factor; TRAP, tartrate-resistant acid phosphatase; TREM2, triggering receptor expressed in myeloid cells 2

\section{Author Contributions}

Writing - original draft: Amarasekara DS;

Writing - review \& editing: Yun H, Kim S, Lee N, Kim H, Rho J. as the osteoclastogenesis inhibitory factor and TNF receptor (TNFR) superfamily member 11b, is secreted by OBs and stromal cells (3). OPG acts as a negative regulator of osteoclastogenesis by binding with RANKL and hindering RANKL-RANK interaction (3). OPG-deficient mice exhibit a decrease in bone mineral density and develop an osteoporotic phenotype (5). Therefore, the RANK/RANKL/OPG axis plays a vital role in bone homeostasis (Fig. 2).

The balance between bone formation and resorption is maintained by tight regulation of cytokine networks. Cytokines control the communication between the skeletal system and the immune system. While physiological levels of cytokines are important in maintaining bone integrity, dysregulated and pathophysiological levels of cytokines are key players in the development of bone diseases (6). In the past 2 decades, there have been considerable advances in the field of osteoimmunology, and the involvement and roles of various cytokines in osteoclastogenesis have been clarified (1-3). In the present report, we will review the current understanding of the impact of cytokine networks in osteoclastogenesis in light of the recent progress in this field.

\section{BONE CELLS}

OBs are of mesenchymal cell origin, and secrete bone matrix to rebuild the matrix resorbed by OCs. OBs incorporate into the bone as osteocytes that become entombed during the process of bone deposition, and act as regulators of mineral metabolism in bone remodeling. OCs are multinucleated giant cells that are derived from hematopoietic stem cells through the monocyte/ macrophage lineage precursors, and are responsible for bone resorption (Fig. 1). As OCs pass through their precursor stage to the mature stage, mononucleated OCs fuse together to produce multinucleated mature OCs that resorb the bone matrix in the presence of macrophage colonystimulating factor (M-CSF) and RANKL $(2,3)$. 


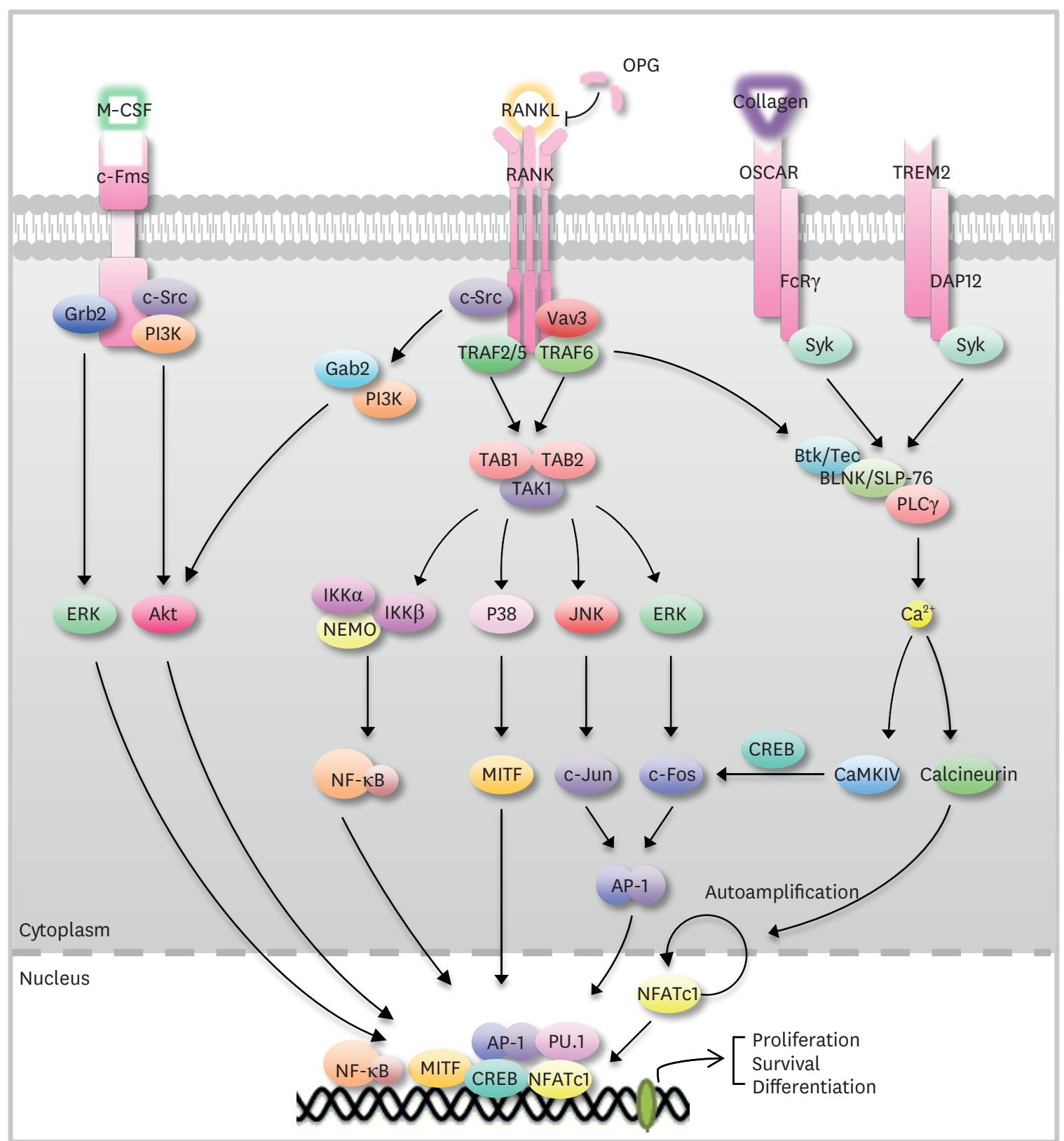

Figure 2. Signaling networks in osteoclastogenesis. Osteoclastogenesis is principally stimulated by RANKL and M-CSF. During the early stage of OC differentiation, M-CSF signaling induces Akt and ERK activation leading to OC proliferation and differentiation. Then, RANKL induces NF-KB, AP-1, CREB, MITF and NFATC1 activation via TRAF6 recruitment and the MAPKs, Akt, Vav3 and c-Src signaling cascades to promote the differentiation of OC precursors into mature OCs. RANKL signaling is further strengthened by TREM2- or OSCAR-mediated costimulatory signaling pathway through the induction of DAP12/FCRY-Syk-PLCY signaling cascades that activate calcium signaling and NFATc1 induction.

Grb2, growth factor receptor bound protein 2; TAK1, transforming growth factor- $\beta$ kinase 1; TAB, transforming growth factor- $\beta$ kinase 1 binding protein; NEMO, NF-KB essential modulator; IKK, inhibitor of IKB kinase; DAP12, DNAX-activating protein 12; FcRY, Fc receptor common Y subunit; BLNK, B-cell linker protein; SLP-76, SH2 domain-containing leukocyte protein of $76 \mathrm{kDa}$; CaMKIV, Ca2 $/$ calmodulin-dependent protein kinase IV; CREB, cyclic adenosine monophosphate response element-binding protein; MITF, microphthalmia transcription factor.

\section{SIGNALING PATHWAYS IN OC DIFFERENTIATION}

OC differentiation, survival, and activity are primarily regulated by two crucial cytokines, M-CSF and RANKL (1-3). The importance of M-CSF in osteoclastogenesis has been demonstrated by several in vivo and in vitro studies (7-9). M-CSF-deficient mice exhibit a severe 
osteopetrotic phenotype due to loss of OC formation and bone resorption (7-9). M-CSF binding to colony-stimulating factor-1 receptor (c-Fms) activates phosphoinositide 3-kinase (PI3K) and growth factor receptor bound protein 2 (Grb2), which further induces Akt and ERK signaling in OC precursors or mature OCs (Fig. 2). Thus, M-CSF is a crucial cytokine for the regulation of $\mathrm{OC}$ proliferation, survival, and differentiation, as well as the fusion of OC precursors and bone resorption of mature OCs (1-3).

RANK, also known as TNFR superfamily member 11a, plays a vital role in osteoclastogenesis (1-3). RANKL-RANK binding recruits TNFR-associated factors (TRAFs) to initiate the activation of downstream signaling cascades of adaptors/kinases such as NF- $\mathrm{kB}$ essential modulator, inhibitor of IкB kinases, c-Src, Vav3, and mitogen-activated protein kinases (MAPKs), including p38, JNK, and ERK (Fig. 2) (1,3,10). The final consequence of RANKL-RANK signaling is the activation of osteoclastogenic transcription factors such as NF- $\mathrm{kB}$, activator protein 1 (AP-1), cyclic adenosine monophosphate response element-binding protein (CREB), and nuclear factor of activated $\mathrm{T}$ cells 1 (NFATc1), all of which induce the expression of osteoclastogenic markers, such as tartrate-resistant acid phosphatase (TRAP), dendritic cell-specific transmembrane protein (DC-STAMP), v-ATPase subunit d2 (Atp6vOd2), OC-associated receptor (OSCAR), $\beta 3$ integrin, osteopetrosis-associated transmembrane protein 1 (OSTM1), B-lymphocyte induced maturation protein 1 (BLIMP1), and cathepsin K (2,3,11-14).

Costimulatory signals via the activation of triggering receptors expressed in myeloid cells 2 (TREM2) or OSCAR are essential for the complete activation of NFATc1 in the RANKLRANK signaling pathway (Fig. 2) $(11,15,16)$. TREM2 and OSCAR transduce signals to the immunoreceptor tyrosine-based activation motif in DNAX-activation protein 12 and the Fc receptor common $\gamma$ subunit, respectively, which activate the downstream signals of Syk and phospholipase C $\gamma 2$ (PLC $\gamma 2)(11,15,16)$. RANK-TRAF6-mediated signaling through Bruton's tyrosine kinase (Tec), adaptor molecules B cell linker protein, and Src homology 2 domaincontaining leukocyte $76 \mathrm{kDa}$ protein also activates PLC $\gamma 2$ signaling (17). Finally, activation of PLC $\gamma 2$ results in calcium mobilization to activate calmodulin-dependent protein kinase-IV and calcineurin, resulting in NFATc1 nuclear translocation and amplification (17).

\section{OSTEOCLASTOGENIC CYTOKINES AND CHEMOKINES}

TNF- $\alpha$, IL-1, IL-6, IL-7, IL-8, IL-11, IL-15, IL-17, IL-23, and IL-34 have been reported as osteoclastogenic cytokines (Table 1). The proinflammatory cytokine TNF- $\alpha$ is a potent inducer of bone resorption and plays an important role in bone metabolism and inflammatory bone diseases (3). TNF- $\alpha$ directly induces the formation of TRAP ${ }^{+}$ multinucleated OCs from OC precursors in the presence of M-CSF and in the absence of RANKL by activating NF- $\kappa B$ signaling (18). TNF- $\alpha$ can induce RANK expression in OC precursors (19). TNF- $\alpha$ may also accelerate RANKL-induced osteoclastogenesis through the activation of TRAF2/5 and MAPKs in TNFR1-mediated signaling, leading to NF- $\kappa \mathrm{B}$ and AP-1 activation (20-23). Interestingly, a recent study reported that TNF- $\alpha$-induced osteoclastogenesis is enhanced in $\mathrm{TRAFG}^{-1-}$ OC precursors by inducing autophagosomal degradation of TRAF3 by RANKL stimulation (24). Thus, RANKL can also enhance TNF- $\alpha-$ induced osteoclastogenesis via the TRAF6-independent signaling pathway (24). TNF- $\alpha$ may indirectly affect osteoclastogenesis by inducing M-CSF and RANKL expression in stromal cells, OBs, and activated T cells (25-27). TNF- $\alpha$ upregulates osteoclastogenic cytokine IL-34 production by activating NF- $\kappa B$ and JNK signaling in the synovial cells of RA patients (28). 
Table 1. Summary of the effects of osteoclastogenic and anti-osteoclastogenic cytokines in osteoclastogenesis.

\begin{tabular}{|c|c|c|}
\hline Cytokine & Action & Reference \\
\hline \multicolumn{3}{|c|}{ Osteoclastogenic cytokines } \\
\hline RANKL & Induces OC differentiation, survival, proliferation, and maturation & $(1-3,10-14)$ \\
\hline M-CSF & Induces OC differentiation, survival, proliferation, and maturation & $(1-3,7-9)$ \\
\hline TNF- $\alpha$ & Induces RANKL and RANK expression; stimulates OC differentiation & $(18-28)$ \\
\hline IL-1a & Induces RANKL and OC marker expression; activates MITF induction & (33) \\
\hline IL-1b & Induces RANKL expression and OC differentiation & $(30-32)$ \\
\hline IL-6 & Induces RANKL and OC marker expression & $(36-38)$ \\
\hline IL-7 & Induces RANKL and TNF- $\alpha$ expression; activates STAT5 & $(41-45)$ \\
\hline IL-8 & Induces RANK-mediated NFATC1 activation & $(47-49)$ \\
\hline IL-11 & Induces OC differentiation; increases OC progenitor cells & $(39,51,52)$ \\
\hline IL-15 & Induces TNF- $\alpha$ and RANKL expression; stimulates OC differentiation & $(53,54)$ \\
\hline IL-17 & Induces RANKL, TNF- $\alpha$, IL-1, and IL-6 expression & $(55-60)$ \\
\hline IL-23 & Induces RANKL and RANK expression; stimulates IL-17 producing Th17 cell expansion & $(63-65)$ \\
\hline IL-34 & Induces OC differentiation; activates STAT3/Smad7 signaling pathway & $(28,66-68)$ \\
\hline \multicolumn{3}{|c|}{ Anti-osteoclastogenic cytokines } \\
\hline OPG & Inhibits OC differentiation (a decoy receptor of RANKL) & $(1-3,5)$ \\
\hline IFN- $\alpha$ & Downregulates c-Fos expression & $(83,84)$ \\
\hline IFN- $\beta$ & $\begin{array}{l}\text { Inhibits RANK- and TLR5-mediated OC differentiation; downregulates JAK1/STAT3/C-Fos } \\
\text { signaling pathway }\end{array}$ & $(85-89)$ \\
\hline IFN- $\gamma$ & Inhibits RANKL- and TNF- $\alpha$-induced OC differentiation; stimulates OC apoptosis & $(94-96)$ \\
\hline IL-3 & Downregulates c-Fms, PU.1, c-Fos, and TNFR expression & $(100-102)$ \\
\hline IL-4 & $\begin{array}{l}\text { Inhibits RANKL-induced NFATc1 induction; downregulates TNF- } \alpha, \text { IL-1, IL-6, and RANKL } \\
\text { expression }\end{array}$ & $(103-107)$ \\
\hline IL-10 & Downregulates NFATc1, IL-1, TNF- $\alpha$, and IL-6 production; induces OPG expression & $(108-110)$ \\
\hline IL-12 & Inhibits RANKL- and TNF- $\alpha$-induced OC differentiation & $(112-114)$ \\
\hline IL-27 & $\begin{array}{l}\text { Inhibits RANKL-induced signaling pathway; downregulates IL-17-mediated Th17 cell } \\
\text { differentiation }\end{array}$ & $(117-121)$ \\
\hline IL-33 & Inhibits RANKL-induced OC differentiation; induces OC apoptosis & $(122-124)$ \\
\hline
\end{tabular}

Thus, TNF- $\alpha$ inhibitors, such as infliximab, adalimumab, certolizumab, and golimumab, have been successfully used in RA patients (29). Taken together, these findings indicate that TNF- $\alpha$ plays a significant role in directly and indirectly promoting osteoclastogenesis.

The proinflammatory cytokine IL-1 $\beta$ is a powerful stimulator of OC differentiation and bone resorption by inducing RANKL expression (30). Similarly, IL-1 $\beta$ indirectly promotes TNF- $\alpha$ induced osteoclastogenesis by enhancing RANKL expression in stromal cells, and directly stimulating OC precursor differentiation under the control of p38 MAPK in the presence of sufficient RANKL levels (31). Sufficient RANKL levels are also needed for IL-1 $\alpha$ to activate the expression of OC markers such as TRAP, cathepsin K, matrix metallopeptidase 9 (MMP9), and NFATc1 (32). IL-1 $\alpha$ can directly induce OC differentiation independently of RANKL by inducing microphthalmia transcription factor (MITF) in bone marrow macrophages (BMMs) (33). Anti-IL-1 therapies, such as IL-1 receptor antagonist (anakinra) and IL-1 blockers (rilonacept and canakinumab), have been applied to RA patients (34). Collectively, IL-1 $\alpha$ and IL-1 $\beta$ are known to be strongly osteoclastogenic cytokines.

The IL-6 family of cytokines shares the signaling receptor subunit gp130 as a part of its receptor complex (35). IL-6 is a pleiotropic cytokine that transduces signals through the IL-6 receptor (IL-6R), and consists of an $\alpha$ chain and a gp130 subunit (35). IL-6 is positively involved in osteoclastogenesis via induction of RANKL expression in OBs and stromal cells (36). IL-6R inhibition results in the blockage of OC formation both in vitro and in vivo (37). In the IL-6/IL-6R signaling pathway, the signal transducer and activator of transcription 3 (STAT3) is activated by JAKs leading to OC marker expression (38). Interestingly, IL-6induced osteoclastogenesis in the presence of M-CSF is not inhibited by OPG treatment in 
human $\mathrm{CD} 14^{+}$monocyte cultures, whereas gp130 antibody treatment significantly reduced IL-6-induced osteoclastogenesis (39). Thus, IL-6 is a potential inducer of OC differentiation independent of RANKL, although the detailed mechanism by which this occurs has not yet been revealed. In general, IL- 6 is a positive regulator of osteoclastogenesis; thus, neutralizing antibody therapy for IL-6R is currently in clinical use to treat inflammatory bone diseases. In contrast to the above findings, a negative role has been reported for IL- 6 in RANKL-induced osteoclastogenesis, where it is involved in suppressing RANK-mediated NF- $\kappa B$ and JNK activation (36). Recently, IL-6/IL-6R signaling has been reported to act differently with regard to NF- $\kappa \mathrm{B}, \mathrm{ERK}$, and JNK activation in the absence or presence of low or high levels of RANKL, indicating that IL- 6 signaling is dependent on the availability of RANKL in the microenvironment (40). Thus, it is possible that the negative role of IL- 6 in osteoclastogenesis is closely associated with the level of RANKL in the microenvironment.

IL-7 is produced by stromal cells and OBs, and can indirectly enhance osteoclastogenesis by inducing RANKL and TNF- $\alpha$ production in T cells (41-43). In osteolytic cancer patients, similarly, IL-7 to enhances OC formation in bone tissues by inducing TNF- $\alpha$ production (44). Moreover, IL-7 production following stimulation by IL-1 $\alpha$ and TNF- $\alpha$ also leads to bone loss by inducing RANKL production in activated T cells, and by enhancing IL-17-producing T helper 17 (Th17) cell expansion (27). A recent study has reported that IL-7 directly induces osteoclastogenesis independently of RANKL by inducing STAT5 activation (45). In contrast to the above findings, it has been reported that IL-7 is a potential inhibitor of osteoclastogenesis in vitro, although the detailed mechanism has not yet been revealed (46). Collectively, IL-7 is an osteoclastogenic cytokine, although some exceptions may exist.

IL-8 is known to be a potential stimulator of OC differentiation and bone destruction in metastatic bone disease (47). The production of IL-8 in OCs by RANKL stimulation enhances RANKL-induced osteoclastogenesis in an autocrine dependent manner, whereas osteoclastogenesis is inhibited by blocking antibodies against IL-8 or treating with IL-8 receptor inhibitors in vitro (48). Thus, IL-8 is an autocrine regulator of osteoclastogenesis to induce RANK-mediated NFATc1 activation (48). A recent study has reported that the level of IL-8 in the serum of anti-citrullinated protein antibody (ACPA)-positive RA patients is increased, and the enhanced formation of bone-resorbing OCs is induced by ACPA binding to their OC precursors (49). Interestingly, ACPA-induced OC differentiation is reduced by treatment with IL-8 neutralizing antibody, highlighting the importance of IL-8 in ACPAinduced OC differentiation in RA patients (49).

IL-11 is a member of the IL-6 family of cytokines, all of which share the coreceptor gp130 (35). IL-11 is produced by stromal cells, and has been identified as a crucial cytokine in osteoclastogenesis (50). Interestingly, IL-11-induced osteoclastogenesis in the presence of $\mathrm{M}-\mathrm{CSF}$ is not inhibited by OPG treatment in human CD14+ monocyte cultures, while anti-gp130 antibody treatment reduced this activity (39). Similar to IL-6, IL-11 also acts as a potential inducer of OC differentiation independent of RANKL. Furthermore, IL-11 produced by breast cancer cells induces osteoclastogenesis by increasing the pool of OC progenitors and by downregulating granulocyte-macrophage colony stimulating factor (GM-CSF) expression $(51,52)$. Based on the available evidence, IL-11 is a positive regulator of osteoclastogenesis.

The proinflammatory cytokine IL-15 is a strong stimulator of TNF- $\alpha$, which induces RANKL expression in OBs and stromal cells, resulting in enhanced osteoclastogenesis (53). IL-15 appears to be a potential osteoclastogenic cytokine that indirectly stimulates RANKL- 
induced osteoclastogenesis. A recent study demonstrated that IL-15 exhibits a synergistic effect with RANKL in osteoclastogenesis by inducing ERK activation (54). Moreover, in rat bone marrow cultures, IL-15 stimulates the differentiation of OC progenitors into OC precursors independent of TNF- $\alpha$, although the mechanism has not been identified yet (53). Taken together, these data indicate that IL-15 is a positive regulator of osteoclastogenesis.

The Th17 cytokine IL-17 is known to be a stimulator of RANKL expression, which leads to loss of the RANKL/OPG balance and consequently induces osteoclastogenesis and bone erosion in animal models of arthritis (55). The progressive destruction of bone and cartilage is significantly reduced in arthritis-induced IL-17-deficient mice (56). Interestingly, it has been reported that IL-17 is a strong stimulator of the expression of osteoclastogenic cytokines such as TNF- $\alpha$, IL-1, IL-6, and IL-8 $(57,58)$. Similarly, in the absence of RANKL, IL-17 can indirectly induce OC differentiation in human monocytes by enhancing TNF- $\alpha$ induced osteoclastogenesis (59). The expression of OC marker genes such as cathepsin K, TRAP, and MMP9 in the synovium of RA patients is synergistically induced by both IL-17 and IL-32, independent of RANKL signaling (60). Correspondingly, the production of the proinflammatory cytokine IL-32 is induced by IL-17, and IL-17 production is also enhanced by IL-32 in the synovium of RA patients (60). Anti-IL-17 therapies, such as secukinumab, ixekizumab, and brodalumab, have been undergoing clinical trials (61). Thus, IL-17 acts indirectly as a stimulator of osteoclastogenesis. In contrast to its osteoclastogenic role, however, IL-17 has also been reported to indirectly inhibit osteoclastogenesis by inducing GM-CSF production in OB lineage cells (62).

IL-23 is a member of the IL-6 family of cytokines and is predominantly secreted by macrophages and dendritic cells (35). IL-23 is positively involved in osteoclastogenesis by inducing RANK expression in OC precursors (63). In cocultures comprising OCs and OBs, OC proliferation and bone resorption are promoted by IL-23 (64). IL-23 is also indirectly involved in osteoclastogenesis by inducing RANKL expression in OBs, and by enhancing the expansion of IL-17-producing Th17 cells $(63,65)$. Collectively, these data suggest that IL-23 is a potential stimulator of osteoclastogenesis.

IL-34 and M-CSF both bind to the c-Fms receptor (66). Concomitant with reports that IL-34 and M-CSF share the c-Fms receptor, IL-34 in combination with RANKL induces OC differentiation and bone resorption from M-CSF-deficient mouse bone marrow cells, and systemic administration of IL-34 reduces bone mass in mice (67). In RA patients, osteoclastogenesis is also induced by TNF- $\alpha$-stimulated IL-34 production in fibroblast-like synovial cells (28). It has been recently reported that the survival and proliferation of OC precursors are maintained by IL-34 via enhanced NFATc1 expression and induced STAT3 and Smad7 activation (68). Thus, IL-34 is an osteoclastogenic cytokine.

GM-CSF is produced by activated T cells, macrophages, endothelial cells, and fibroblasts, and enhances osteoclastogenesis (69). GM-CSF stimulates OC fusion by activating Ras/ ERK signaling (70). Moreover, GM-CSF increases the number of OC precursors in the bone, which further contributes to its osteoclastogenic properties (71). A different report has stated that TNF- $\alpha$-induced GM-CSF expression is negatively involved in osteoclastogenesis, as it distresses the hematopoietic precursors. This activity potentially occurs by suppressing c-Fos, Fra-1, and NFATc1 activation (72). The functional role of GM-CSF in osteoclastogenesis is still controversial. 
Chemokines are small cytokines induced by the inflammatory response (73) and play an important role in osteoclastogenesis (74). The levels of CXCL8, CXCL9, CXCL10, and CCL20 are elevated in inflammatory bone diseases $(75,76)$. Recent studies have revealed that CXCL8 and CCL20 play a role in osteoclastogenesis by modulating IL-6 production in primary OBs (76). Similarly, CXCL10 indirectly induces osteoclastogenesis by promoting RANKL and TNF- $\alpha$ expression in activated $\mathrm{CD}^{+} \mathrm{T}$ cells (77). Reciprocally, RANKL also induces CXCL10 expression in OC precursors (77). CXCL2 induced by RANKL stimulation enhances the proliferation of OC precursors by inducing ERK activation (78). CX3CL1 derived from OBs enhances osteoclastogenesis by inducing the adhesion of OC precursors to the bone resorption site (79). A recent study demonstrated that CCL4 is as an important regulator of OC migration via induction of PI3K activation (80). Furthermore, CCL2 (MIP-1), CCL5 (RANTES), CCL7 (MCP-3), and CXCL12 (SDF-1) can also induce OC migration, resorption activity, adhesion, and survival $(81,82)$.

\section{ANTI-OSTEOCLASTOGENIC CYTOKINES}

IFN- $\alpha$, IFN- $\beta$, IFN- $\gamma$, IL-3, IL-4, IL-10, IL-12, IL-27, and IL-33 have been implicated as antiosteoclastogenic cytokines (Table 1). IFNs are a group of cytokines that play a vital role in the immune system (3). IFN- $\alpha$ and IFN- $\beta$ are type I IFNs, and play an inhibitory role in RANKL-induced osteoclastogenesis (83). IFN- $\alpha$ inhibits RANKL-induced osteoclastogenesis by reducing c-Fos expression (84). The inhibitory effects of IFN- $\beta$ in osteoclastogenesis are regulated by the JAK1/STAT3/c-Fos signaling pathway (85). It has also been suggested that IFN- $\beta$ inhibits osteoclastogenesis by enhancing nitric oxide (NO) production and inducible NO synthase signaling (86). Interestingly, it has been reported that enhancing IFN- $\beta$ expression via RANKL stimulation inhibits osteoclastogenesis by downregulating c-Fos activation (87). IFN- $\beta$ production by osteocytes to inhibit osteoclastogenesis has also been reported (88). Enhancing IFN- $\beta$ production by activating the signaling of toll-like receptor 5 (TLR5) inhibits osteoclastogenesis in a c-Fos-dependent manner (89). IFN- $\beta$ therefore appears to be a negative feedback regulator of RANKL-induced osteoclastogenesis (87). However, several studies also revealed that type I IFN signaling is involved in the production of proinflammatory cytokines and the activation of inflammasome during certain bacterial and viral infections (90-93). Thus, under certain conditions, type 1 IFN- $\beta$ may indirectly exert osteoclastogenic roles through the induction of proinflammatory cytokines.

IFN- $\gamma$, a type II IFN, is secreted predominantly by natural killer (NK) cells, NKT cells, Th1 cells, and cytotoxic $\mathrm{T}$ cells (3). IFN- $\gamma$ production by anti-CD3-activated $\mathrm{T}$ cells strongly inhibits RANK-mediated signaling by inducing ubiquitin-dependent TRAF6 degradation in vitro (94). The increased number of OCs and enhanced bone loss are also exhibited in IFN- $\gamma$ receptor-deficient mice (94). Moreover, IFN- $\gamma$ directly inhibits TNF- $\alpha$-induced osteoclastogenesis by inducing Fas/FasL-mediated apoptosis in BMM-derived OCs (95). Interestingly, the inhibitory action of IFN- $\gamma$ in osteoclastogenesis acts cooperatively with the TLR signaling pathways by downregulating RANK and c-Fms expression in OC precursors (96). In contrast to these findings, IFN- $\gamma$ has a positive role in osteoclastogenesis under specific pathophysiological conditions (97-99). The loss of IFN- $\gamma$ expression has been implicated in protection against infection-induced bone destruction in IFN- $\gamma$-deficient mice (97). Furthermore, IFN- $\gamma$ production by antigen-driven T cell activation indirectly enhances osteoclastogenesis by inducing RANKL and TNF- $\alpha$ expression in activated T cells (98). Thus, $\mathrm{CD}^{+} \mathrm{T}$ cells cytokines are important for inducing bone loss by OCs under 
pathophysiological conditions (97). Under estrogen deficient conditions, bone loss is also enhanced by IFN- $\gamma$ production by T cells induced by ovariectomy, leading to activation and expansion of TNF-producing T cell populations (98). Moreover, IFN- $\gamma$ can directly positively stimulate the fusion of mononuclear OCs in vitro (99). Thus, under certain conditions, such as infection, inflammation, and estrogen deficiency, IFN- $\gamma$ can induce bone destruction by enhancing osteoclastogenesis, but this activity might be closely associated with the levels of osteoclastogenic cytokines in the local environment. Taken together, these data suggest that IFN- $\gamma$ has a potentially dual role in osteoclastogenesis, by supporting both direct antiosteoclastogenic and indirect osteoclastogenic properties depending on the physiological or pathophysiological conditions. However, the direct osteoclastogenic properties of IFN- $\gamma$ still remain poorly understood.

IL-3 acts as an anti-osteoclastogenic cytokine. IL-3 secreted by activated T cells inhibits OC differentiation and bone resorption by downregulating the expression of c-Fms, PU.1, and c-Fos $(100,101)$. IL-3 also blocks TNF- $\alpha$-induced osteoclastogenesis by downregulating TNFR expression (102).

IL-4, a Th2 cytokine, inhibits RANKL- and TNF- $\alpha$-induced osteoclastogenesis by inhibiting the NF- $\mathrm{KB}$ and MAPK signaling pathways (103). In RANKL-induced osteoclastogenesis, IL-4 directly inhibits RANKL-induced NFATc1 expression by antagonizing NF- $\mathrm{\kappa B}$ activation in a STAT6-dependent manner (104). Indirectly, IL-4 is also negatively involved in osteoclastogenesis by decreasing the production of proinflammatory and osteoclastogenic cytokines such as TNF- $\alpha$, IL-1 and IL-6 (105). Similar to the role of IL-4, the Th2 cytokine IL-13 is an anti-osteoclastogenic cytokine that can bind to the IL- 4 receptor- $\alpha$ along with IL-4, and exerts its effects by decreasing RANKL expression and by increasing OPG expression in OBs in a STAT-dependent manner (106). Both IL-4 and IL-13 inhibit bone resorption by suppressing IL-1 $\alpha$-induced prostaglandin synthesis in OBs (107). Thus, IL-4 and IL-13 are anti-osteoclastogenic cytokines.

IL-10, a Th2 cytokine, is a known potent suppressor of osteoclastogenesis via inhibition of NFATc1 expression and its nuclear translocation (108). IL-10 upregulates the expression of OPG, and downregulates the expression of RANKL and M-CSF (109). IL-10 inhibits osteoclastogenesis by downregulating the production of osteoclastogenic cytokines such as TNF- $\alpha$, IL-1, and IL-6 (110). IL-10 can therefore be considered to be an anti-osteoclastogenic cytokine.

IL-12 is produced by monocytes, macrophages, and dendritic cells, whereas IL-18 is mainly produced by macrophages, Kupffer cells, and OBs (111). IL-12 inhibits RANKL-induced osteoclastogenesis by inducing OC apoptosis (112). IL-18 also inhibits TNF- $\alpha$-induced osteoclastogenesis by activating Fas/FasL-mediated apoptosis $(113,114)$. IL-12 and IL-18 synergistically inhibit TNF- $\alpha$-induced osteoclastogenesis by inducing Fas/FasL signaling or NO production, resulting in apoptosis $(111,114)$. IL-18 was first identified for its osteoclastogenic role, similar to that of IL- 1 and TNF- $\alpha$ (115). However, the role of IL-18 in osteoclastogenesis is currently controversial, due to a recent report on the synergistic effects of IL-18 and IL-12 on inhibiting osteoclastogenesis (116).

IL-27 belongs to the IL-6/IL-12 family of cytokines, and is known to suppress RANKL-induced osteoclastogenesis by inhibiting STAT1-dependent c-Fos activation and by reducing IL-17mediated Th17 cell differentiation (117). IL-27 inhibits the cell surface expression of RANKL in $\mathrm{CD}^{+} \mathrm{T}$ cells, which could contribute to the suppressive effects of IL-27 on inflammatory bone 
destruction (118). It has been reported that IL-27 inhibits the expression of c-Fos and NFATc1 by blocking RANK-mediated ERK, p38, and NF- $\kappa B$ activation in OC precursors $(119,120)$. A recent study also revealed the protective role of IL-27 in bone loss in estrogen-deficient conditions by inducing anti-osteoclastogenic regulators such as early growth response gene 2 and Id2 (121). Collectively, these data indicate that IL-23 is a potential anti-osteoclastogenic cytokine.

The anti-osteoclastogenic effects of IL-33 have been described previously $(122,123)$. IL-33 inhibits RANKL-induced osteoclastogenesis by modulating BLIMP1 and interferon regulatory factor 8 expression (122). IL-33 also induces OC apoptosis by increasing the expression of proapoptotic molecules such BAX, Fas, and FasL (123). In transgenic mice overexpressing human TNF- $\alpha$, IL-33 played a protective role in TNF- $\alpha$-induced bone loss by decreasing the number of OCs (124). Overall, these studies confirm that IL-33 is an osteoprotective cytokine.

Macrophage migration inhibitory factor (MIF) acts as a negative regulator of osteoclastogenesis $(125,126)$. MIF reduces RANK-mediated NFATc1 activation by downregulating calcium signaling (125). Osteoclastogenesis is enhanced in MIF receptor (CD74)-deficient mice (126). In addition to its inhibitory role in osteoclastogenesis, MIF indirectly induces osteoclastogenesis by enhancing RANKL expression in the synovial cells of RA patients (127).

\section{CONCLUDING REMARKS}

Osteoclastogenic and anti-osteoclastogenic cytokines play pivotal roles in osteoclastogenesis by networking between the skeletal and immune systems. Dysregulation of cytokines can lead to pathological bone diseases, and it is therefore important to maintain physiological levels of osteoclastogenic and anti-osteoclastogenic cytokines. Proinflammatory cytokines such as TNF- $\alpha$, IL-1, and IL- 6 act as potent osteoclastogenic cytokines, which induce robust induction of OC differentiation, whereas anti-inflammatory cytokines such as IL-4, IL-10, IFN- $\alpha$, and IFN- $\beta$ act as potent anti-osteoclastogenic cytokines. However, many questions regarding the exact mechanisms and instances upon which these cytokines act remain unanswered. In the present review, we discuss the effects of cytokine networks on osteoclastogenesis. Synthesizing the information available in current studies describing the regulation of cytokine networks in osteoclastogenesis will be helpful to develop pharmaceutical targets as remedies for bone diseases caused by cytokine dysregulation in the future.

\section{ACKNOWLEDGEMENTS}

This research was supported by a grant from the Ministry of the National Defense Foundation Grant (ADD: 08-10-02, 14-01-06-06), by the Basic Science Research Program through the National Research Foundation of Korea (NRF) and was funded by the Ministry of Education (NRF-2017R1A2B4007327), and by the research fund of Chungnam National University.

\section{REFERENCES}

1. Rho J, Takami M, Choi Y. Osteoimmunology: interactions of the immune and skeletal systems. Mol Cells 2004;17:1-9.

PUBMED 
2. Takayanagi H. Osteoimmunology: shared mechanisms and crosstalk between the immune and bone systems. Nat Rev Immunol 2007;7:292-304. PUBMED | CROSSREF

3. Walsh MC, Kim N, Kadono Y, Rho J, Lee SY, Lorenzo J, Choi Y. Osteoimmunology: interplay between the immune system and bone metabolism. Annu Rev Immunol 2006;24:33-63. PUBMED | CROSSREF

4. Wong BR, Josien R, Lee SY, Sauter B, Li HL, Steinman RM, Choi Y. TRANCE (tumor necrosis factor [TNF]-related activation-induced cytokine), a new TNF family member predominantly expressed in $\mathrm{T}$ cells, is a dendritic cell-specific survival factor. J Exp Med 1997;186:2075-2080. PUBMED | CROSSREF

5. Bucay N, Sarosi I, Dunstan CR, Morony S, Tarpley J, Capparelli C, Scully S, Tan HL, Xu W, Lacey DL, et al. osteoprotegerin-deficient mice develop early onset osteoporosis and arterial calcification. Genes Dev 1998;12:1260-1268. PUBMED | CROSSREF

6. Amarasekara DS, Yu J, Rho J. Bone loss triggered by the cytokine network in inflammatory autoimmune diseases. J Immunol Res 2015;2015:832127. PUBMED | CROSSREF

7. Yoshida H, Hayashi S, Kunisada T, Ogawa M, Nishikawa S, Okamura H, Sudo T, Shultz LD, Nishikawa S. The murine mutation osteopetrosis is in the coding region of the macrophage colony stimulating factor gene. Nature 1990;345:442-444. PUBMED | CROSSREF

8. Wiktor-Jedrzejczak W, Bartocci A, Ferrante AW Jr, Ahmed-Ansari A, Sell KW, Pollard JW, Stanley ER. Total absence of colony-stimulating factor 1 in the macrophage-deficient osteopetrotic (op/op) mouse. Proc Natl Acad Sci U S A 1990;87:4828-4832. PUBMED | CROSSREF

9. Takahashi N, Udagawa N, Akatsu T, Tanaka H, Shionome M, Suda T. Role of colony-stimulating factors in osteoclast development. J Bone Miner Res 1991;6:977-985. PUBMED | CROSSREF

10. Yu J, Yun H, Shin B, Kim Y, Park ES, Choi S, Yu J, Amarasekara DS, Kim S, Inoue J, et al. Interaction of tumor necrosis factor receptor-associated factor 6 (TRAF6) and Vav3 in the receptor activator of nuclear factor $\mathrm{\kappa B}$ (RANK) signaling complex enhances osteoclastogenesis. J Biol Chem 2016;291:20643-20660. PUBMED | CROSSREF

11. Kim N, Takami M, Rho J, Josien R, Choi Y. A novel member of the leukocyte receptor complex regulates osteoclast differentiation. J Exp Med 2002;195:201-209. PUBMED | CROSSREF

12. Lee SH, Rho J, Jeong D, Sul JY, Kim T, Kim N, Kang JS, Miyamoto T, Suda T, Lee SK, et al. v-ATPase VO subunit d2-deficient mice exhibit impaired osteoclast fusion and increased bone formation. Nat Med 2006;12:1403-1409. PUBMED | CROSSREF

13. Rho J, Altmann CR, Socci ND, Merkov L, Kim N, So H, Lee O, Takami M, Brivanlou AH, Choi Y. Gene expression profiling of osteoclast differentiation by combined suppression subtractive hybridization (SSH) and cDNA microarray analysis. DNA Cell Biol 2002;21:541-549. PUBMED | CROSSREF

14. Shin B, Yu J, Park ES, Choi S, Yu J, Hwang JM, Yun H, Chung YH, Hong KS, Choi JS, et al. Secretion of a truncated osteopetrosis-associated transmembrane protein 1 (OSTM1) mutant inhibits osteoclastogenesis through down-regulation of the B lymphocyte-induced maturation protein 1 (BLIMP1)-nuclear factor of activated T cells c1 (NFATc1) axis. J Biol Chem 2014;289:35868-35881. PUBMED | CROSSREF

15. Barrow AD, Raynal N, Andersen TL, Slatter DA, Bihan D, Pugh N, Cella M, Kim T, Rho J, Negishi-Koga T, et al. OSCAR is a collagen receptor that costimulates osteoclastogenesis in DAP12-deficient humans and mice. J Clin Invest 2011;121:3505-3516. PUBMED | CROSSREF

16. Koga T, Inui M, Inoue K, Kim S, Suematsu A, Kobayashi E, Iwata T, Ohnishi H, Matozaki T, Kodama T, et al. Costimulatory signals mediated by the ITAM motif cooperate with RANKL for bone homeostasis. Nature 2004;428:758-763. PUBMED | CROSSREF

17. Walsh MC, Choi Y. Biology of the RANKL-RANK-OPG system in immunity, bone, and beyond. Front Immunol 2014;5:511. PUBMED | CROSSREF 
18. Azuma Y, Kaji K, Katogi R, Takeshita S, Kudo A. Tumor necrosis factor-alpha induces differentiation of and bone resorption by osteoclasts. J Biol Chem 2000;275:4858-4864. PUBMED | CROSSREF

19. Komine M, Kukita A, Kukita T, Ogata Y, Hotokebuchi T, Kohashi O. Tumor necrosis factor-alpha cooperates with receptor activator of nuclear factor kappaB ligand in generation of osteoclasts in stromal cell-depleted rat bone marrow cell culture. Bone 2001;28:474-483. PUBMED | CROSSREF

20. Kanazawa K, Azuma Y, Nakano H, Kudo A. TRAF5 functions in both RANKL- and TNFalpha-induced osteoclastogenesis. J Bone Miner Res 2003;18:443-450. PUBMED | CROSSREF

21. Kanazawa K, Kudo A. TRAF2 is essential for TNF-alpha-induced osteoclastogenesis. J Bone Miner Res 2005;20:840-847.

PUBMED | CROSSREF

22. Park ES, Choi S, Shin B, Yu J, Yu J, Hwang JM, Yun H, Chung YH, Choi JS, Choi Y, et al. Tumor necrosis factor (TNF) receptor-associated factor (TRAF)-interacting protein (TRIP) negatively regulates the TRAF2 ubiquitin-dependent pathway by suppressing the TRAF2-sphingosine 1-phosphate (S1P) interaction.J Biol Chem 2015;290:9660-9673.

PUBMED | CROSSREF

23. Zhang YH, Heulsmann A, Tondravi MM, Mukherjee A, Abu-Amer Y. Tumor necrosis factor- $\alpha$ (TNF) stimulates RANKL-induced osteoclastogenesis via coupling of TNF type 1 receptor and RANK signaling pathways. J Biol Chem 2001;276:563-568. PUBMED | CROSSREF

24. Yao Z, Lei W, Duan R, Li Y, Luo L, Boyce BF. RANKL cytokine enhances TNF-induced osteoclastogenesis independently of TNF receptor associated factor (TRAF) 6 by degrading TRAF3 in osteoclast precursors. $J$ Biol Chem 2017;292:10169-10179. PUBMED | CROSSREF

25. Kitaura H, Kimura K, Ishida M, Kohara H, Yoshimatsu M, Takano-Yamamoto T. Immunological reaction in TNF- $\alpha$-mediated osteoclast formation and bone resorption in vitro and in vivo. Clin Dev Immunol 2013;2013:181849. PUBMED | CROSSREF

26. Kitaura H, Zhou P, Kim HJ, Novack DV, Ross FP, Teitelbaum SL. M-CSF mediates TNF-induced inflammatory osteolysis. J Clin Invest 2005;115:3418-3427. PUBMED | CROSSREF

27. Weitzmann MN, Cenci S, Rifas L, Brown C, Pacifici R. Interleukin-7 stimulates osteoclast formation by up-regulating the T-cell production of soluble osteoclastogenic cytokines. Blood 2000;96:1873-1878. PUBMED

28. Hwang SJ, Choi B, Kang SS, Chang JH, Kim YG, Chung YH, Sohn DH, So MW, Lee CK, Robinson WH, et al. Interleukin-34 produced by human fibroblast-like synovial cells in rheumatoid arthritis supports osteoclastogenesis. Arthritis Res Ther 2012;14:R14. PUBMED | CROSSREF

29. Corrado A, Neve A, Maruotti N, Cantatore FP. Bone effects of biologic drugs in rheumatoid arthritis. Clin Dev Immunol 2013;2013:945945.

PUBMED | CROSSREF

30. Ruscitti P, Cipriani P, Carubbi F, Liakouli V, Zazzeroni F, Di Benedetto P, Berardicurti O, Alesse $\mathrm{E}$, Giacomelli R. The role of IL-1 $\beta$ in the bone loss during rheumatic diseases. Mediators Inflamm 2015;2015:782382. PUBMED | CROSSREF

31. Wei S, Kitaura H, Zhou P, Ross FP, Teitelbaum SL. IL-1 mediates TNF-induced osteoclastogenesis. J Clin Invest 2005;115:282-290. PUBMED | CROSSREF

32. Jules J, Zhang PAshley JW, Wei S, Shi Z, Liu J, Michalek SM, Feng X. Molecular basis of requirement of receptor activator of nuclear factor $\mathrm{\kappa B}$ signaling for interleukin 1-mediated osteoclastogenesis. J Biol Chem 2012;287:15728-15738. CROSSREF

33. Kim JH, Jin HM, Kim K, Song I, Youn BU, Matsuo K, Kim N. The mechanism of osteoclast differentiation induced by IL-1. J Immunol 2009;183:1862-1870. PUBMED | CROSSREF

34. Dinarello CA, Simon A, van der Meer JW. Treating inflammation by blocking interleukin-1 in a broad spectrum of diseases. Nat Rev Drug Discov 2012;11:633-652.

PUBMED | CROSSREF 
35. Rose-John S. Interleukin-6 family cytokines. Cold Spring Harb Perspect Biol. doi: 10.1101/cshperspect.a028415. PUBMED | CROSSREF

36. Yoshitake F, Itoh S, Narita H, Ishihara K, Ebisu S. Interleukin-6 directly inhibits osteoclast differentiation by suppressing receptor activator of NF-kappaB signaling pathways. J Biol Chem 2008;283:11535-11540. PUBMED | CROSSREF

37. Axmann R, Böhm C, Krönke G, Zwerina J, Smolen J, Schett G. Inhibition of interleukin-6 receptor directly blocks osteoclast formation in vitro and in vivo. Arthritis Rheum 2009;60:2747-2756. PUBMED | CROSSREF

38. Blanchard F, Duplomb L, Baud'huin M, Brounais B. The dual role of IL-6-type cytokines on bone remodeling and bone tumors. Cytokine Growth Factor Rev 2009;20:19-28. PUBMED | CROSSREF

39. Kudo O, Sabokbar A, Pocock A, Itonaga I, Fujikawa Y, Athanasou NA. Interleukin-6 and interleukin-11 support human osteoclast formation by a RANKL-independent mechanism. Bone 2003;32:1-7. PUBMED | CROSSREF

40. Feng W, Liu H, Luo T, Liu D, Du J, Sun J, Wang W, Han X, Yang K, Guo J, et al. Combination of IL-6 and sIL-6R differentially regulate varying levels of RANKL-induced osteoclastogenesis through NF- $\mathrm{B}$, ERK and JNK signaling pathways. Sci Rep 2017;7:41411. PUBMED | CROSSREF

41. Aguila HL, Mun SH, Kalinowski J, Adams DJ, Lorenzo JA, Lee SK. Osteoblast-specific overexpression of human interleukin-7 rescues the bone mass phenotype of interleukin-7-deficient female mice. J Bone Miner Res 2012;27:1030-1042. PUBMED | CROSSREF

42. Toraldo G, Roggia C, Qian WP, Pacifici R, Weitzmann MN. IL-7 induces bone loss in vivo by induction of receptor activator of nuclear factor kappa B ligand and tumor necrosis factor alpha from T cells. Proc Natl Acad Sci U S A 2003;100:125-130. PUBMED | CROSSREF

43. Yu J, Choi S, Kim H, Lee N, Yun H, Kim S, Jeong ST, Rho J. Generation of an osteoblast-based artificial niche that supports in vitro B lymphopoiesis. Exp Mol Med 2017;49:e400. PUBMED | CROSSREF

44. Roato I, Brunetti G, Gorassini E, Grano M, Colucci S, Bonello L, Buffoni L, Manfredi R, Ruffini E, Ottaviani D, et al. IL-7 up-regulates TNF- $\alpha$-dependent osteoclastogenesis in patients affected by solid tumor. PLoS One 2006;1:e124. PUBMED | CROSSREF

45. Kim JH, Sim JH, Lee S, Seol MA, Ye SK, Shin HM, Lee EB, Lee YJ, Choi YJ, Yoo WH, et al. Interleukin-7 induces osteoclast formation via STAT5, independent of receptor activator of NF-kappaB ligand. Front Immunol 2017;8:1376. PUBMED | CROSSREF

46. Lee SK, Kalinowski JF, Jastrzebski SL, Puddington L, Lorenzo JA. Interleukin-7 is a direct inhibitor of in vitro osteoclastogenesis. Endocrinology 2003;144:3524-3531. PUBMED | CROSSREF

47. Bendre MS, Montague DC, Peery T, Akel NS, Gaddy D, Suva LJ. Interleukin-8 stimulation of osteoclastogenesis and bone resorption is a mechanism for the increased osteolysis of metastatic bone disease. Bone 2003;33:28-37. PUBMED | CROSSREF

48. Kopesky P, Tiedemann K, Alkekhia D, Zechner C, Millard B, Schoeberl B, Komarova SV. Autocrine signaling is a key regulatory element during osteoclastogenesis. Biol Open 2014;3:767-776. PUBMED | CROSSREF

49. Liu Y, Krishnamurthy A, Hensvold AH, Joshua V, Sun M, Engstrom M, Wähämaa H, Malmström V, Jopling LA, Rethi B, et al. AB0078 Role of IL-8 and its receptor in anti-citrullinated protein antibody mediated osteoclastogenesis in RA. Ann Rheum Dis 2016;75:923. CROSSREF

50. Girasole G, Passeri G, Jilka RL, Manolagas SC. Interleukin-11: a new cytokine critical for osteoclast development. J Clin Invest 1994;93:1516-1524. PUBMED | CROSSREF

51. McCoy EM, Hong H, Pruitt HC, Feng X. IL-11 produced by breast cancer cells augments osteoclastogenesis by sustaining the pool of osteoclast progenitor cells. BMC Cancer 2013;13:16. PUBMED | CROSSREF

52. Morgan H, Tumber A, Hill PA. Breast cancer cells induce osteoclast formation by stimulating host IL-11 production and downregulating granulocyte/macrophage colony-stimulating factor. Int J Cancer 2004;109:653-660. PUBMED | CROSSREF 
53. Ogata Y, Kukita A, Kukita T, Komine M, Miyahara A, Miyazaki S, Kohashi O. A novel role of IL-15 in the development of osteoclasts: inability to replace its activity with IL-2. J Immunol 1999;162:2754-2760. PUBMED

54. Okabe I, Kikuchi T, Mogi M, Takeda H, Aino M, Kamiya Y, Fujimura T, Goto H, Okada K, Hasegawa Y, et al. IL-15 and RANKL play a synergistically important role in osteoclastogenesis J Cell Biochem 2017;118:739-747. PUBMED | CROSSREF

55. Lubberts E, van den Bersselaar L, Oppers-Walgreen B, Schwarzenberger P, Coenen-de Roo CJ, Kolls JK, Joosten LA, van den Berg WB. IL-17 promotes bone erosion in murine collagen-induced arthritis through loss of the receptor activator of NF- $\kappa$ B ligand/osteoprotegerin balance. J Immunol 2003;170:2655-2662. PUBMED | CROSSREF

56. Lubberts E, Koenders MI, van den Berg WB. The role of T-cell interleukin-17 in conducting destructive arthritis: lessons from animal models. Arthritis Res Ther 2005;7:29-37. PUBMED | CROSSREF

57. Hwang SY, Kim JY, Kim KW, Park MK, Moon Y, Kim WU, Kim HY. IL-17 induces production of IL-6 and IL-8 in rheumatoid arthritis synovial fibroblasts via NF-kappaB- and PI3-kinase/Akt-dependent pathways. Arthritis Res Ther 2004;6:R120-R128. PUBMED | CROSSREF

58. Jovanovic DV, Di Battista JA, Martel-Pelletier J, Jolicoeur FC, He Y, Zhang M, Mineau F, Pelletier JP. IL-17 stimulates the production and expression of proinflammatory cytokines, IL-beta and TNF-alpha, by human macrophages. J Immunol 1998;160:3513-3521. PUBMED

59. Yago T, Nanke Y, Ichikawa N, Kobashigawa T, Mogi M, Kamatani N, Kotake S. IL-17 induces osteoclastogenesis from human monocytes alone in the absence of osteoblasts, which is potently inhibited by anti-TNF-alpha antibody: a novel mechanism of osteoclastogenesis by IL-17. J Cell Biochem 2009;108:947-955. PUBMED | CROSSREF

60. Moon YM, Yoon BY, Her YM, Oh HJ, Lee JS, Kim KW, Lee SY, Woo YJ, Park KS, Park SH, et al. IL-32 and IL-17 interact and have the potential to aggravate osteoclastogenesis in rheumatoid arthritis. Arthritis Res Ther 2012;14:R246. PUBMED | CROSSREF

61. Kellner H. Targeting interleukin-17 in patients with active rheumatoid arthritis: rationale and clinical potential. Ther Adv Musculoskelet Dis 2013;5:141-152.

PUBMED | CROSSREF

62. Balani D, Aeberli D, Hofstetter W, Seitz M. Interleukin-17A stimulates granulocyte-macrophage colonystimulating factor release by murine osteoblasts in the presence of 1,25-dihydroxyvitamin $\mathrm{D}(3)$ and inhibits murine osteoclast development in vitro. Arthritis Rheum 2013;65:436-446. PUBMED | CROSSREF

63. Chen L, Wei XQ, Evans B, Jiang W, Aeschlimann D. IL-23 promotes osteoclast formation by up-regulation of receptor activator of NF-kappaB (RANK) expression in myeloid precursor cells. Eur J Immunol 2008;38:2845-2854. PUBMED | CROSSREF

64. Kang YK, Zhang MC. IL-23 promotes osteoclastogenesis in osteoblast-osteoclast co-culture system. Genet Mol Res 2014;13:4673-4679. PUBMED | CROSSREF

65. Iwakura Y, Ishigame H. The IL-23/IL-17 axis in inflammation. J Clin Invest 2006;116:1218-1222. PUBMED | CROSSREF

66. Chihara T, Suzu S, Hassan R, Chutiwitoonchai N, Hiyoshi M, Motoyoshi K, Kimura F, Okada S. IL-34 and M-CSF share the receptor Fms but are not identical in biological activity and signal activation. Cell Death Differ 2010;17:1917-1927. PUBMED | CROSSREF

67. Chen Z, Buki K, Vääräniemi J, Gu G, Väänänen HK. The critical role of IL-34 in osteoclastogenesis. PLoS One 2011;6:e18689. PUBMED | CROSSREF

68. Cheng X, Wan QL, Li ZB. AG490 suppresses interleukin-34-mediated osteoclastogenesis in mice bone marrow macrophages. Cell Biol Int 2017;41:659-668. PUBMED | CROSSREF

69. Shi Y, Liu CH, Roberts AI, Das J, Xu G, Ren G, Zhang Y, Zhang L, Yuan ZR, Tan HS, et al. Granulocytemacrophage colony-stimulating factor (GM-CSF) and T-cell responses: what we do and don't know. Cell Res 2006;16:126-133. PUBMED | CROSSREF 
70. Lee MS, Kim HS, Yeon JT, Choi SW, Chun CH, Kwak HB, Oh J. GM-CSF regulates fusion of mononuclear osteoclasts into bone-resorbing osteoclasts by activating the Ras/ERK pathway. J Immunol 2009;183:3390-3399. PUBMED | CROSSREF

71. Ruef N, Dolder S, Aeberli D, Seitz M, Balani D, Hofstetter W. Granulocyte-macrophage colony-stimulating factor-dependent CD11c-positive cells differentiate into active osteoclasts. Bone 2017;97:267-277. PUBMED | CROSSREF

72. Atanga E, Dolder S, Dauwalder T, Wetterwald A, Hofstetter W. TNF $\alpha$ inhibits the development of osteoclasts through osteoblast-derived GM-CSF. Bone 2011;49:1090-1100. PUBMED | CROSSREF

73. Mackay CR. Chemokines: immunology's high impact factors. Nat Immunol 2001;2:95-101. PUBMED | CROSSREF

74. Lee SH, Kim TS, Choi Y, Lorenzo J. Osteoimmunology: cytokines and the skeletal system. BMB Rep 2008;41:495-510. PUBMED | CROSSREF

75. Kuan WP, Tam LS, Wong CK, Ko FW, Li T, Zhu T, Li EK. CXCL 9 and CXCL 10 as Sensitive markers of disease activity in patients with rheumatoid arthritis. J Rheumatol 2010;37:257-264. PUBMED | CROSSREF

76. Pathak JL, Bakker AD, Verschueren P, Lems WF, Luyten FP, Klein-Nulend J, Bravenboer N. CXCL8 and CCL20 enhance osteoclastogenesis via modulation of cytokine production by human primary osteoblasts. PLoS One 2015;10:e0131041.

PUBMED | CROSSREF

77. Kwak HB, Ha H, Kim HN, Lee JH, Kim HS, Lee S, Kim HM, Kim JY, Kim HH, Song YW, et al. Reciprocal cross-talk between RANKL and interferon-gamma-inducible protein 10 is responsible for bone-erosive experimental arthritis. Arthritis Rheum 2008;58:1332-1342. PUBMED | CROSSREF

78. Ha J, Choi HS, Lee Y, Kwon HJ, Song YW, Kim HH. CXC chemokine ligand 2 induced by receptor activator of NF-kappa B ligand enhances osteoclastogenesis. J Immunol 2010;184:4717-4724. PUBMED | CROSSREF

79. Koizumi K, Saitoh Y, Minami T, Takeno N, Tsuneyama K, Miyahara T, Nakayama T, Sakurai H, Takano Y, Nishimura M, et al. Role of CX3CL1/fractalkine in osteoclast differentiation and bone resorption. $J$ Immunol 2009;183:7825-7831. PUBMED | CROSSREF

80. Xuan W, Feng X, Qian C, Peng L, Shi Y, Xu L, Wang F, Tan W. Osteoclast differentiation gene expression profiling reveals chemokine CCL4 mediates RANKL-induced osteoclast migration and invasion via PI3K pathway. Cell Biochem Funct 2017;35:171-177. PUBMED | CROSSREF

81. Yu X, Huang Y, Collin-Osdoby P, Osdoby P. Stromal cell-derived factor-1 (SDF-1) recruits osteoclast precursors by inducing chemotaxis, matrix metalloproteinase-9 (MMP-9) activity, and collagen transmigration. J Bone Miner Res 2003;18:1404-1418. PUBMED | CROSSREF

82. Yu X, Huang Y, Collin-Osdoby P, Osdoby P. CCR1 chemokines promote the chemotactic recruitment, RANKL development, and motility of osteoclasts and are induced by inflammatory cytokines in osteoblasts. J Bone Miner Res 2004;19:2065-2077. PUBMED | CROSSREF

83. Xiong Q, Zhang L, Ge W, Tang P. The roles of interferons in osteoclasts and osteoclastogenesis. Joint Bone Spine 2016;83:276-281. PUBMED | CROSSREF

84. Avnet S, Cenni E, Perut F, Granchi D, Brandi ML, Giunti A, Baldini N. Interferon-alpha inhibits in vitro osteoclast differentiation and renal cell carcinoma-induced angiogenesis. Int J Oncol 2007;30:469-476. PUBMED

85. Lee Y, Hyung SW, Jung HJ, Kim HJ, Staerk J, Constantinescu SN, Chang EJ, Lee ZH, Lee SW, Kim HH. The ubiquitin-mediated degradation of Jak1 modulates osteoclastogenesis by limiting interferon-beta-induced inhibitory signaling. Blood 2008;111:885-893. PUBMED | CROSSREF

86. Zheng H, Yu X, Collin-Osdoby P, Osdoby P. RANKL stimulates inducible nitric-oxide synthase expression and nitric oxide production in developing osteoclasts. An autocrine negative feedback mechanism triggered by RANKL-induced interferon-beta via NF-kappaB that restrains osteoclastogenesis and bone resorption. J Biol Chem 2006;281:15809-15820.

PUBMED | CROSSREF 
87. Takayanagi H, Sato K, Takaoka A, Taniguchi T. Interplay between interferon and other cytokine systems in bone metabolism. Immunol Rev 2005;208:181-193.

PUBMED | CROSSREF

88. Hayashida C, Ito J, Nakayachi M, Okayasu M, Ohyama Y, Hakeda Y, Sato T. Osteocytes produce interferon- $\beta$ as a negative regulator of osteoclastogenesis. J Biol Chem 2014;289:11545-11555. PUBMED | CROSSREF

89. Ha H, Lee JH, Kim HN, Kwak HB, Kim HM, Lee SE, Rhee JH, Kim HH, Lee ZH. Stimulation by TLR5 modulates osteoclast differentiation through STAT1/IFN-beta. J Immunol 2008;180:1382-1389. PUBMED | CROSSREF

90. Henry T, Brotcke A, Weiss DS, Thompson LJ, Monack DM. Type I interferon signaling is required for activation of the inflammasome during Francisella infection. J Exp Med 2007;204:987-994. PUBMED | CROSSREF

91. Kopitar-Jerala N. The role of interferons in inflammation and inflammasome activation. Front Immunol 2017;8:873. PUBMED | CROSSREF

92. Makris S, Paulsen M, Johansson C. Type I interferons as regulators of lung inflammation. Front Immunol 2017;8:259. PUBMED | CROSSREF

93. Thomas KE, Galligan CL, Newman RD, Fish EN, Vogel SN. Contribution of interferon-beta to the murine macrophage response to the toll-like receptor 4 agonist, lipopolysaccharide. J Biol Chem 2006;281:31119-31130. PUBMED | CROSSREF

94. Takayanagi H, Ogasawara K, Hida S, Chiba T, Murata S, Sato K, Takaoka A, Yokochi T, Oda H, Tanaka $\mathrm{K}$, et al. T-cell-mediated regulation of osteoclastogenesis by signalling cross-talk between RANKL and IFN- $\gamma$. Nature 2000;408:600-605. PUBMED | CROSSREF

95. Kohara H, Kitaura H, Fujimura Y, Yoshimatsu M, Morita Y, Eguchi T, Masuyama R, Yoshida N. IFN- $\gamma$ directly inhibits TNF- $\alpha$-induced osteoclastogenesis in vitro and in vivo and induces apoptosis mediated by Fas/Fas ligand interactions. Immunol Lett 2011;137:53-61. PUBMED | CROSSREF

96. Ji JD, Park-Min KH, Shen Z, Fajardo RJ, Goldring SR, McHugh KP, Ivashkiv LB. Inhibition of RANK expression and osteoclastogenesis by TLRs and IFN-gamma in human osteoclast precursors. JImmunol 2009;183:7223-7233. PUBMED | CROSSREF

97. Baker PJ, Dixon M, Evans RT, Dufour L, Johnson E, Roopenian DC. CD4(+) T cells and the proinflammatory cytokines gamma interferon and interleukin-6 contribute to alveolar bone loss in mice. Infect Immun 1999;67:2804-2809. PUBMED

98. Gao Y, Grassi F, Ryan MR, Terauchi M, Page K, Yang X, Weitzmann MN, Pacifici R. IFN-gamma stimulates osteoclast formation and bone loss in vivo via antigen-driven T cell activation. J Clin Invest 2007;117:122-132. PUBMED | CROSSREF

99. Kim JW, Lee MS, Lee CH, Kim HY, Chae SU, Kwak HB, Oh J. Effect of interferon- $\gamma$ on the fusion of mononuclear osteoclasts into bone-resorbing osteoclasts. BMB Rep 2012;45:281-286. PUBMED | CROSSREF

100. Gupta N, Barhanpurkar AP, Tomar GB, Srivastava RK, Kour S, Pote ST, Mishra GC, Wani MR. IL-3 inhibits human osteoclastogenesis and bone resorption through downregulation of c-Fms and diverts the cells to dendritic cell lineage. J Immunol 2010;185:2261-2272. PUBMED | CROSSREF

101. Lee J, Seong S, Kim JH, Kim K, Kim I, Jeong BC, Nam KI, Kim KK, Hennighausen L, Kim N. STAT5 is a key transcription factor for IL-3-mediated inhibition of RANKL-induced osteoclastogenesis. Sci Rep 2016;6:30977. PUBMED | CROSSREF

102. Yogesha SD, Khapli SM, Wani MR. Interleukin-3 and granulocyte-macrophage colony-stimulating factor inhibits tumor necrosis factor (TNF)- $\alpha$-induced osteoclast differentiation by down-regulation of expression of TNF receptors 1 and 2. J Biol Chem 2005;280:11759-11769. PUBMED | CROSSREF

103. Wei S, Wang MW, Teitelbaum SL, Ross FP. Interleukin-4 reversibly inhibits osteoclastogenesis via inhibition of NF-kappa B and mitogen-activated protein kinase signaling. J Biol Chem 2002;277:6622-6630. PUBMED | CROSSREF 
104. Cheng J, Liu J, Shi Z, Xu D, Luo S, Siegal GP, Feng X, Wei S. Interleukin-4 inhibits RANKL-induced NFATc1 expression via STAT6: a novel mechanism mediating its blockade of osteoclastogenesis. J Cell Biochem 2011;112:3385-3392. PUBMED | CROSSREF

105. te Velde AA, Huijbens RJ, Heije K, de Vries JE, Figdor CG. Interleukin-4 (IL-4) inhibits secretion of IL-1 beta, tumor necrosis factor alpha, and IL-6 by human monocytes. Blood 1990;76:1392-1397. PUBMED

106. Stein NC, Kreutzmann C, Zimmermann SP, Niebergall U, Hellmeyer L, Goettsch C, Schoppet M, Hofbauer LC. Interleukin-4 and interleukin-13 stimulate the osteoclast inhibitor osteoprotegerin by human endothelial cells through the STAT6 pathway. J Bone Miner Res 2008;23:750-758. PUBMED | CROSSREF

107. Onoe Y, Miyaura C, Kaminakayashiki T, Nagai Y, Noguchi K, Chen QR, Seo H, Ohta H, Nozawa S, Kudo I, et al. IL-13 and IL-4 inhibit bone resorption by suppressing cyclooxygenase-2-dependent prostaglandin synthesis in osteoblasts. J Immunol 1996;156:758-764. PUBMED

108. Evans KE, Fox SW. Interleukin-10 inhibits osteoclastogenesis by reducing NFATc1 expression and preventing its translocation to the nucleus. BMC Cell Biol 2007;8:4 PUBMED | CROSSREF

109. Liu D, Yao S, Wise GE. Effect of interleukin-10 on gene expression of osteoclastogenic regulatory molecules in the rat dental follicle. Eur J Oral Sci 2006;114:42-49. PUBMED | CROSSREF

110. Houri-Haddad Y, Soskolne WA, Halabi A, Shapira L. IL-10 gene transfer attenuates P. gingivalis-induced inflammation. J Dent Res 2007;86:560-564. PUBMED | CROSSREF

111. Kitaura H, Fujimura Y, Yoshimatsu M, Kohara H, Morita Y, Aonuma T, Fukumoto E, Masuyama R, Yoshida N, Takano-Yamamoto T. IL-12- and IL-18-mediated, nitric oxide-induced apoptosis in TNF- $\alpha$ mediated osteoclastogenesis of bone marrow cells. Calcif Tissue Int 2011;89:65-73. PUBMED | CROSSREF

112. Nagata N, Kitaura H, Yoshida N, Nakayama K. Inhibition of RANKL-induced osteoclast formation in mouse bone marrow cells by IL-12: involvement of IFN-gamma possibly induced from non-T cell population. Bone 2003;33:721-732. PUBMED | CROSSREF

113. Kitaura H, Tatamiya M, Nagata N, Fujimura Y, Eguchi T, Yoshida N, Nakayama K. IL-18 induces apoptosis of adherent bone marrow cells in TNF- $\alpha$ mediated osteoclast formation in synergy with IL-12. Immunol Lett 2006;107:22-31. PUBMED | CROSSREF

114. Morita Y, Kitaura H, Yoshimatsu M, Fujimura Y, Kohara H, Eguchi T, Yoshida N. IL-18 inhibits TNF-alphainduced osteoclastogenesis possibly via a T cell-independent mechanism in synergy with IL-12 in vivo. Calcif Tissue Int 2010;86:242-248. PUBMED | CROSSREF

115. Dai SM, Nishioka K, Yudoh K. Interleukin (IL) 18 stimulates osteoclast formation through synovial T cells in rheumatoid arthritis: comparison with IL1 beta and tumour necrosis factor alpha. Ann Rheum Dis 2004;63:1379-1386. PUBMED | CROSSREF

116. Horwood NJ, Elliott J, Martin TJ, Gillespie MT. IL-12 alone and in synergy with IL-18 inhibits osteoclast formation in vitro. J Immunol 2001;166:4915-4921. PUBMED | CROSSREF

117. Furukawa M, Takaishi H, Takito J, Yoda M, Sakai S, Hikata T, Hakozaki A, Uchikawa S, Matsumoto M, Chiba K, et al. IL-27 abrogates receptor activator of NF-kappa B ligand-mediated osteoclastogenesis of human granulocyte-macrophage colony-forming unit cells through STAT1-dependent inhibition of c-Fos. J Immunol 2009;183:2397-2406. PUBMED | CROSSREF

118. Kamiya S, Okumura M, Chiba Y, Fukawa T, Nakamura C, Nimura N, Mizuguchi J, Wada S, Yoshimoto T. IL-27 suppresses RANKL expression in CD4+ T cells in part through STAT3. Immunol Lett 2011;138:47-53. PUBMED | CROSSREF

119. Zolochevska O, Diaz-Quiñones AO, Ellis J, Figueiredo ML. Interleukin-27 expression modifies prostate cancer cell crosstalk with bone and immune cells in vitro. J Cell Physiol 2013;228:1127-1136. PUBMED | CROSSREF 
120. Kalliolias GD, Zhao B, Triantafyllopoulou A, Park-Min KH, Ivashkiv LB. Interleukin-27 inhibits human osteoclastogenesis by abrogating RANKL-mediated induction of nuclear factor of activated $\mathrm{T}$ cells $\mathrm{c} 1$ and suppressing proximal RANK signaling. Arthritis Rheum 2010;62:402-413.

PUBMED | CROSSREF

121. Shukla P, Mansoori MN, Kakaji M, Shukla M, Gupta SK, Singh D. Interleukin 27 (IL-27) alleviates bone loss in estrogen-deficient conditions by induction of early growth response-2 gene. J Biol Chem 2017;292:4686-4699. PUBMED | CROSSREF

122. Kiyomiya H, Ariyoshi W, Okinaga T, Kaneuji T, Mitsugi S, Sakurai T, Habu M, Yoshioka I, Tominaga K, Nishihara T. IL-33 inhibits RANKL-induced osteoclast formation through the regulation of Blimp-1 and IRF-8 expression. Biochem Biophys Res Commun 2015;460:320-326. PUBMED | CROSSREF

123. Lima IL, Macari S, Madeira MF, Rodrigues LF, Colavite PM, Garlet GP, Soriani FM, Teixeira MM, Fukada SY, Silva TA. Osteoprotective effects of IL-33/ST2 link to osteoclast apoptosis. Am J Pathol 2015;185:3338-3348. PUBMED | CROSSREF

124. Zaiss MM, Kurowska-Stolarska M, Böhm C, Gary R, Scholtysek C, Stolarski B, Reilly J, Kerr S, Millar NL, Kamradt T, et al. IL-33 shifts the balance from osteoclast to alternatively activated macrophage differentiation and protects from TNF-alpha-mediated bone loss. J Immunol 2011;186:6097-6105. PUBMED | CROSSREF

125. Mun SH, Oh D, Lee SK. Macrophage migration inhibitory factor down-regulates the RANKL-RANK signaling pathway by activating Lyn tyrosine kinase in mouse models. Arthritis Rheumatol 2014;66:2482-2493. PUBMED | CROSSREF

126. Mun SH, Won HY, Hernandez P, Aguila HL, Lee SK. Deletion of CD74, a putative MIF receptor, in mice enhances osteoclastogenesis and decreases bone mass. J Bone Miner Res 2013;28:948-959. PUBMED | CROSSREF

127. Gu R, Santos LL, Ngo D, Fan H, Singh PP, Fingerle-Rowson G, Bucala R, Xu J, Quinn JM, Morand EF. Macrophage migration inhibitory factor is essential for osteoclastogenic mechanisms in vitro and in vivo mouse model of arthritis. Cytokine 2015;72:135-145.

PUBMED | CROSSREF 